\title{
8. The European Union: from impotence to opportunity?
}

\author{
Tully Fletcher
}

\section{The European Union and the global financial crisis}

The European Union is a curious and constantly evolving political institution and the way in which EU leaders have managed their responses to the global financial crisis draws out its unusual and at times opaque approach to crisis management. Economic decision-making power is divided between the leaders and finance ministers of the European member states through the European Council and the Council of Ministers, the European Commission (the central executive bureaucracy), the European Central Bank (ECB, which administers the common monetary policy) and the increasingly powerful European Parliament (McCormick 2005:79-91). It is often impossible to divorce the coordinated crisis-management response of the European Union from the actions of its constituent member states. It is also easy to underplay the significance of EU institutions and their actions once a common position has been adopted. As the global financial crisis struck Europe, its leaders eventually managed to overcome their initial paralysis and weld a stronger, more systematic Europe-wide response.

The EU member states initially dealt with the crisis on an individual basis, but by the end of 2008, the European Union's complex array of leaders was manoeuvring to adopt a common approach to the management of the crisis and coordinate a strong Europe-wide response through the commission and the Central Bank. By the end of October 2008, a 'European Framework for Action' had been adopted. By the end of November, a substantial multi-billion-euro stimulus plan had been announced. A record-breaking cut was made to interest rates in early December; and, at the G20 meeting of leading global economies in March 2009, coordinated EU pressure had provided much of the momentum for global agreements on new financial and banking regulation and economic stimuli. The crisis had demonstrated the combined power of the European institutions and provided an opportunity for Europe to develop a stronger common economic approach.

It is in that context that this chapter assesses the meaning making of three key actors in the European Union: the Commission President José Manuel Durão Barroso, the Commissioner for Economic and Financial Affairs Joaquín Almunia, and the President of the ECB Jean-Claude Trichet. Each of these actors was a significant decision maker and leader within the European Union's institutional 
framework vested with significant responsibility to respond to the economic changes across the European Union as a whole. Until the end of 2008, the Presidency of the European Council (often described as the EU Presidency) was held by France and exercised by French President, Nicolas Sarkozy. Despite the leadership potential of this latter office (Tallberg 2006), this chapter sets to one side the deliberations of member state and 'intergovernmental' (that is, the presidency) leaders and focuses on the roles of the 'supranational' leaders. The Commission President is a significant, influential and vocal EU leader in his own right (McCormick 2005:82-6; Verbeek forthcoming). This chapter found that the European Union's key leaders sought to frame the crisis in such a way as to avoid harmful political blame and achieve effective economic cooperation, substantial structural reforms in banking and finance regulation and a heightened sense of European unity. In the process, the institutional leaders of the European Union helped to drive a significant shift in macroeconomic ideology and policy to a more interventionist style.

\section{Box 8.1 The European Union's financial crisis trajectory, July 2008 - March 2009}

I July 2008: French Presidency of the European Union begins.

3 September: The ECB cuts the growth forecast for 2009 from 1.5 per cent to 1.2 per cent.

8 October: Central banks around the world coordinate an interest rate cut in response to the credit crunch. The ECB cuts rates from 4.25 per cent to 3.75 per cent.

I2 October: An emergency summit is held of national leaders of the eurozone countries. An agreement is reached regarding measures to repair confidence, promote cooperation among European leaders and ensure liquidity for financial institutions.

15-16 October: An EU summit is held and there are calls for reform of the international financial system.

I8 October: Commission President Barroso and current EU President, Nicolas Sarkozy, meet with US President, George W. Bush, to discuss the global financial crisis. A series of meetings of international leaders to review national and international responses is established.

6 November: The ECB cuts rates from 3.75 per cent to 3.25 per cent.

7 November: EU Summit held (informal gathering of EU member state leaders) and agrees on a common set of reform principles for the International Monetary Fund (IMF). 
9 November: São Paulo, Brazil, hosts G20 meeting of finance ministers and central bank governors, including EU member state representatives.

I4 November: The eurozone officially enters recession after figures for the European Union show a 0.2 per cent contraction of the economy in the third quarter of 2008.

I5 November: The EU-initiated G20 summit is held in Washington, DC, bringing together 19 of the largest national economies; includes EU representation as well as senior figures of the United Nations, the IMF, World Bank and the Financial Stability Forum.

I9 November: Memorandum of understanding signed on financial assistance to Hungary - to provide up to $€ 6.5$ billion, with the first $€ 2$ billion instalment released before the year's end.

26 November: The European Commission releases the European Economic Recovery Plan, worth $€ 200$ billion, with the goal of boosting confidence in the financial systems and stimulating spending throughout the European Union.

28 November: Inflation in the eurozone had been at 3.2 per cent in October 2008, but falls to 2.1 per cent.

4 December: ECB cuts interest rate from 2.75 per cent to 2.5 per cent - the greatest reduction since the euro currency was introduced.

II-I2 December: The European Council approves the European Economic Recovery Plan. The plan provides a common framework across the European Union and is worth approximately $€ 2$ billion or 1.5 per cent of the European Union's gross domestic product (GDP).

I January 2009: Czech Presidency of the European Union begins.

I5 January: The ECB cuts eurozone interest rates a further 0.5 per cent to 2 per cent.

26 January: Memorandum of understanding signed on financial assistance to Latvia - to provide up to $€ 3.1$ billion assistance.

9 February: EU Commissioner for Economic and Monetary Affairs Joaquín Almunia's article 'Solve the toxic asset problem' is published in the Wall Street Journal.

I March: EU leaders attend an informal European Council meeting and establish an agreement on measures to deal with banks' toxic assets

5 March: ECB announces further cuts in the interest rate- to 1.5 per cent. 
II March: Supplemental memorandum of understanding with Hungary - announcing the second instalment of $€ 2$ billion (of up to $€ 6.5$ billion).

I4 March: G20 finance ministers and central bank governors meet in the United Kingdom ahead of the 2 April London G20 summit.

25 March: European Union expresses its intention to provide up to $€ 5$ billion assistance to Romania.

\section{Methodological considerations}

Obtaining speeches made by the three key EU leaders during the period under study was simple, as EU institutions keep extensive online records and key speeches, and crisis updates were readily distinguishable from more mundane announcements, especially during the financial crisis. It proved much more difficult to conduct a study of media responses to those speeches that would be on a par with those conducted for the national case studies reported elsewhere in this volume. Perhaps reflecting the widely acknowledged knowledge deficit (and absence of a well-established 'public sphere') associated with EU institutions (McCormick 2005:135-6), the wide array of commentary and critique from established and accessible print media readily available for national leaders is less evident for EU institutional leaders. ${ }^{1}$ Nevertheless, some consistent but limited press coverage of and responses to the key speeches were available in four of the world's most respected international English-language news sources: The New York Times, The Financial Times, The Guardian and Reuters. All four widely circulating sources carry large international sections and a commitment to observing the behaviour and news of the European institutions. With the exception of The Guardian (a noted British left-wing newspaper), all media sources used here are relatively centrist in political terms, although The Financial Times is skewed towards financial reporting and is pro-market. Despite their quality, the coverage of the crisis by these sources focused on national leaders in Europe and articles were sparse. One or two additional articles were used from the respected American paper The Washington Post and Germany's popular Der Spiegel (available online in English).

To supplement the media response, the responses and attitudes of the national leaders of the three largest European states have also been used to demonstrate the level of consensus achieved across the European Union. As such, this chapter includes an overview of the positions adopted by French President, Nicolas Sarkozy (who was also the EU President until the end of 2008), German Chancellor, Angela Merkel, and British Prime Minister, Gordon Brown. Their positions will be compared with those adopted by the key EU institutional leaders in order to assess the latter's success in the 'framing contests' that developed 
around the global financial crisis (see Chapter 2, this volume). The leaders of member states are as much a part of the audience for statements from EU institutional leaders as are the EU citizenry. Of course, the obvious limitation of this methodology is that it is entirely debatable who influences whom in the EU structure, particularly in terms of the relationship between the European Council and the commission. For the purposes of the analysis in this chapter, however, the extent of success for an EU institutional leader in the framing contest has been determined by the extent to which the views of the three key national leaders were in concert with the EU leaders.

\section{The President of the European Commission}

\section{Barroso's key speech acts}

\section{October 2008: European 'Framework for Action'}

On 29 October 2008, Commission President Barroso made a set of remarks after an extraordinary commission meeting called to provide an initial response to the global financial crisis. His speech marked one of the commission's first comprehensive statements on the crisis. Barroso firmly acknowledged the crisis and its risks and sought to portray it as an opportunity for increased European cooperation and solidarity, and a chance to implement complementary policies for growth and sustainability. He also flagged an upcoming and comprehensive EU recovery plan to be presented in November.

Barroso opened by telling reporters that 'the Commission has set out how we can move from financial crisis to sustainable recovery'. There was no explicit explanation of what was occurring (or why it was happening), though he briefly described the problem as a 'downturn' and a threat to European employment and economic stability. The speech dealt primarily with the management plan Barroso set out as part of the European response to the financial crisis. He pushed firmly for European coordination, solidarity and partnership and argued that the EU funds designed to assist members should now be put to use. He also reiterated the importance of the euro and suggested that the European Union would be much worse off without the single currency.

'We must swim together or sink together,' Barroso said, before setting the groundwork for the later stimulus plan:

We must keep unemployment to the absolute minimum and support those who have lost their jobs. We will review how we can reinforce the effectiveness of the Globalisation Adjustment Fund. We will encourage Member States to re-programme funds under the European Social Fund, to support measures to quickly get unemployed people back into work. I also want to work with Member States to see if we can build on the progress already made under the Lisbon Strategy to help people, in 
particular unemployed people, to start up new businesses quickly and cheaply.

The president also suggested that the European response to the crisis should take into account priorities in energy efficiency and climate change mitigation:

There is scope to provide new opportunities for the economy, including for small and medium-sized enterprises [SMEs] while at the same time helping the EU to meet other objectives, like those I have mentioned on climate change...For example, investment in energy efficiency in buildings can provide opportunities for the construction sector while contributing to tackling climate change.

Though Barroso did not play the blame game in the statement, there was a clear inference that the crisis had exogenous causes. Barroso rhetorically accepted responsibility to act but not fault. The president framed the crisis as an exogenous event through which Europe might be further united: 'Europe will come through this economic storm and emerge stronger'.

\section{November 2008: the stimulus plan}

The themes of the European Framework for Action statement of the previous month were continued when President Barroso announced the $€ 200$ billion economic stimulus package in the European Economic Recovery Plan in Brussels on 26 November 2008. Barroso was more explicit this time in outlining his view of the risk presented by the financial crisis:

Business as usual is not an option. That would lead to a vicious recessionary cycle. It would lead to falling purchasing power and falling tax revenues, to rising unemployment and the accompanying human misery, to ever wider budget deficits, ultimately to a risk of social instability. That is the lesson of the 1930s.

He also presented a qualification, however, on the nature of the stimulus package and warned that

short-term spending without structural reform and without a smart strategy for investing and paying back the borrowing can fuel a downward spiral of debt and unemployment in the future. The cost of fighting this crisis must not be a worse crisis in the future as we struggle to deal with a hangover of debt.

Again, there was no particular apportionment of responsibility for causing the crisis, but there was a detailed plan for management of the crisis through various proposals for structural reform including measures to create labour demand, enhanced finance access for businesses, improved energy efficiency, high-speed 
internet and increased investment in research and development in the green manufacturing sector.

Again, Barroso attempted to frame the crisis as an opportunity for greater European integration and cooperation: 'The full extent of the benefits of individual Member States' fiscal measures will only be reaped if they are part of a co-ordinated European response'. The emerging theme in Barroso's commentary on the crisis was that the crisis was serious, but presented a significant opportunity to implement reforms that had been long considered. His tone was one of optimism and confidence and he sought to portray the European Union as an active player doing everything it could to address the crisis, in what Chapter 2 of this volume would characterise as a strong, type- 3 framing statement:

In all crises there lies also opportunity. And there is an opportunity now, for Member States and European institutions, indeed for European citizens, to understand that acting together, we can make the most of the instruments we have at national and Community level. We can succeed, not only for the good of Europe and European citizens, but also for the good of the world... There are no miracle solutions and it will not happen overnight. But I believe Europe will come through this economic storm and emerge stronger.

\section{February 2009: banking regulation}

After the commission meeting on 25 February 2009, Barroso emerged to announce that the commission would be seeking to strengthen banking supervision across the union and to develop new levels of European cooperation in finance generally. This time the president was less circumspect about the apportionment of blame and squarely laid the blame for the crisis at the feet of 'hubris' in the banking and finance sector:

The crisis has shown why we must deepen our supervisory cooperation at EU level. Why we must have better crisis management systems. Why we must be able to have a basic core set of high level rules - both regulatory and supervisory - that are rigorously applied to all firms, by top class supervisors. Why we must avoid what Jacques de Larosière calls chacun pour soi solutions - everyman for himself - with no concern whatsoever about the neighbours. That is not good enough. It never was. And now it is totally unacceptable... Workers and families across Europe and the world have suffered the consequences of hubris in the financial markets. Citizens expect us to change the rules of the game and the way the game operates. We must not let citizens down.

Barroso reiterated his position that the correct approach to the management of the crisis was through increased European cooperation and noted that this was 
especially important in the lead-up to the approaching G20 summit. A consistent framing pattern had emerged in which Barroso either implied or explicitly deflected causal responsibility (though it could have been argued that the European Union had failed to adequately regulate and supervise the financial and banking sector before the emergence of the crisis), but portrayed an active and comprehensive European response designed to address and mitigate the effects of the crisis.

\section{March 2009: the G20}

Barroso's championing of European coherence reached new heights on 31 March 2009 just before the G20 meeting:

The G20 will not end this crisis overnight. But it can, it must, it will, make a difference. For the first time ever in an economic crisis, the world is working together - and not against each other. The European Union is leading by example. There is convergence around the EU's common position. We have a unique opportunity to re-shape globalisation.

He argued that 'the EU was the first to act. For example on credit rating agencies, on capital requirements, on deposit guarantees. The Commission will very soon take action on hedge funds, private equity and remuneration'. This was grand (and likely hyperbolic) language, which rhetorically placed the European Union at the centre of things.

Again, the president was much less circumspect about attributing the blame for the financial crisis, highlighting a lack of market ethics and inadequate regulation of hedge funds, credit ratings agencies, accounting standards, remuneration, tax havens and 'uncooperative' jurisdictions. The proactivity of Barroso's proposals and the commission's position neatly sidestepped any question of prior failure to act on Europe's part.

\section{Media responses to Barroso's framing}

There was little coverage in the chosen media of the earlier 'framework for action' and Barroso's approach to the G20 summit; however, there was a substantial media response to the commission's European Economic Recovery Plan. The New York Times reported the stimulus package on 26 November 2008 with a relatively supportive tone, quoting Barroso extensively. The New York Times also quoted a leading economist who, approvingly, noted that the package was 'more ambitious' than had been expected. Some cynicism was expressed about German cooperation with the plan and the possibility of complete European cooperation (Castle and Jolly 2008).

In contrast, The Guardian took a more sceptical stance, noting that the commission's plan was designed to 'seize the initiative' after lagging behind the responses of other countries: 'Barroso and the Commission have come under 
criticism in recent weeks for being behind the curve on the financial meltdown and the depressing economic climate. Today's proposals appeared to be an attempt to catch up' (Traynor 2008) This contradicted Barroso's claim that the commission's response so far had been active and comprehensive. The Guardian's report also criticised the stimulus package for being 'unclear' on everything from where the money was coming from to whether it would work at all. Finally, the report suggested that the plans were less an European Commission initiative and more of a repackaging of measures already announced by Germany and Spain.

The Guardian was also scathing of the European Union's proposals for an increase in banking regulation, noting on 24 February 2009 that the hedge fund and private equity industry will this week launch a last-ditch effort to head off EU moves to impose draconian regulation in the wake of the continuing financial crisis' (Gow 2009). The story drew attention to the significant divisions at the top of the commission's governance structure, driven by French, German and British disagreement about the reach and extent of proposed regulation. Though Barroso had called for cooperation generally, he had not alluded in his announcement to the existence of pervasive political divisions (Traynor 2008).

The key framing contest here seemed to be whether the European Commission had acted promptly or appropriately in response to the crisis. Though it did not appear to be strongly challenged by the media, Barroso himself certainly engaged in a consistent portrayal of the crisis as a key opportunity to implement a raft of structural economic reforms and bring forward planned investments and policy changes. Skirting over considerable disagreement among member states about the size and nature of stimuli packages as well the regulatory implications of the crisis that were in plain view, he tried - with some success - to muster political will and public support for concerted action at the European level.

\section{EU Commissioner for Economic and Financial Affairs}

\section{Almunia's key speech acts}

\section{November 2008: a recipe for recovery}

On 11 November 2008, Commissioner Almunia gave a speech to the second Brussels International Economic Forum titled 'A recipe for recovery: the European response to the financial crisis'. Almunia was explicit in identifying the crisis and its causes, arguing that

after the period of excess and risk accumulation in the financial sector, we are now living through a painful market correction. The financial system is enduring a phase of severe deleveraging, characterised by dysfunctional credit markets, unprecedented write-downs in asset 
valuations, generalised risk aversion, and threats to the stability of the banking sector.

He went on to state that 'from the beginning', Europe had taken 'decisive action' with an injection of capital into credit-starved banking institutions and cutting interest rates and the unprecedented level of coordination across Europe in the response. The commissioner also argued (and perhaps pre-empted comments about hindsight and lack of action) that 'the last months have exposed the weaknesses in our financial systems'.

In terms of the proposed management of the crisis, Almunia echoed many of the commission president's stated priorities and argued for long-term reforms in increased research and development, projects for a green economy, energy efficiency and a strong and coordinated European response. Almunia, however, also had another priority and argued for the preservation of the free-trade area in Europe and an aggressive international campaign against protectionism and barriers to global trade:

We also need to work together to prevent protectionism from taking hold. In developed and developing countries alike, economic nationalism is on the rise and the benefits of globalisation are being questioned following the crisis. This is understandable. But history tells us that it is a dangerous tendency, one that can turn a downturn into a protracted and more severe problem...It is vital that we in Europe reaffirm our commitment to the principle of openness and lead by example. We must uphold the competition rules that underpin the Single Market and come out strongly against trade barriers.

In general, Almunia framed the crisis as one with exogenous causes (inadequately regulated international financial institutions), but accepted (as did Barroso) responsibility to address the underlying factors and treat the symptoms of the crisis. These were to be achieved with European cooperation and increased supervision, but avoiding protectionist measures.

\section{February 2009: interview with The Financial Times}

On 25 February, Commissioner Almunia granted a wide-ranging interview with The Financial Times (see Atkins and Barber 2009). He did not discuss the crisis or its causes specifically but rather assessed the European management of the crisis and some of the challenges it presented. He was more circumspect than the commission president on the effect of the European stimulus and noted that the 'degree of co-ordination could be seriously improved...I don't say the present fiscal stimulus is useless at all. But the efficiency of the stimulus will be increased if the degree of co-ordination is improved'. 
Almunia made the inference that the poorly regulated finance and banking sector (including tax havens) was to blame and expressed his support for stronger and 'broader' financial regulation:

The financial system will be more regulated. This will mean less leverage, less flexibility in the financial system, and less influence for the financial system in the aggregated results of our economy...Either we accept that our growth will be lower than in the past because the stimulus from the financial sector will be smaller.

He also noted, however, that the present level of direct state intervention in banks would be temporary and that, in time, 'capitalism' would return to business as usual: 'I don't think we'll go back to the high level of state intervention and public regulation in industry or other sectors'. The commissioner seemed to be striking an almost apologetic tone, clearly regretting the changes that were being made and the increased level of government intervention in the economy, but still supporting the necessity of the measures being put in place.

\section{May 2009: spring forecast}

On 4 May 2009, Almunia delivered his spring forecast on the economic and financial state of the union and its key institutions. The forecast opened with a 'nutshell' summary that provided a neat synopsis of the commissioner's frame of the crisis:

Intensification of financial crisis and sharp contraction in world trade drove global and EU economies into recession; Financial markets gradually stabilising, but remain fragile; Ambitious EU and government action key to achieving stabilisation towards end 2009 and moderate growth in 2010; [and] Leading indicators provide some positive signals.

The commissioner called the financial crisis Europe's 'deepest and most widespread recession since World War $\mathrm{II}^{\prime}$, but he attributed a gradual stabilisation to the 'swift and massive intervention' of the European Community through the European Economic Recovery Plan. Almunia noted that the projections were for a recovery in the coming quarters thanks to the fiscal stimulus measures, the bank rescue plans and monetary easing. He also argued that the fiscal stimuli should continue into the future in order to effectively manage the crisis over time. Essentially, the framing sought here was that the crisis had exogenous causes, but was being dealt with effectively by European authorities.

\section{Media responses to Almunia's framing}

Overall, explicit and systematic coverage of Almunia's speeches was poor; his public visibility when addressing the European Union's handling of the global financial crisis outside Brussels was largely eclipsed by that of Commission 
President Barroso. In response to Almunia's 'recipe for recovery' speech on 11 November 2008, The Financial Times called into question the commission's claim to be pioneering the proposed measures. Though Almunia (like Barroso) claimed much of the credit for the European response, The Financial Times noted that:

Economists said some governments were already proceeding along the lines suggested by Mr Almunia. The ruling coalition in Germany, for example, wants to offer tax incentives for the installation of energy-efficient home heating systems or the purchase of cars emitting lower levels of carbon dioxide. (Barber 2008)

The Financial Times journalist also suggested that the individual EU governments had taken the lead in drawing up the main emergency rescue measures for the banking sector, though the commission had been responsible for some of the subsequent specific details (Barber 2008). The contest here appeared to be over whether the commission had in fact been providing leadership in the crisis or whether it had just adopted measures already being undertaken and claimed them as its own.

\section{The President of the European Central Bank}

\section{Trichet's key speech acts}

\section{December 2008: cutting interest rates}

At the press conference after a meeting of the governors of the ECB, President Trichet announced a decision to cut interest rates by 75 basis points (the biggest cut the ECB had ever made) after two 50-point reductions in the previous two months. This was the direct response to what the ECB had identified as a significant reduction in inflation, attributed to the 'intensifying and broadening' financial crisis. Pointing to 'global economic weakness', Trichet told journalists:

The economic outlook remains surrounded by an exceptionally high degree of uncertainty. Risks to economic growth lie on the downside. They relate mainly to the potential for a more significant impact on the real economy of the turmoil in financial markets, as well as concerns about protectionist pressures and possible disorderly developments owing to global imbalances.

Like the two commissioners, Trichet highlighted the need for disciplined and uniform policymaking across the European Union. The purpose of this was, Trichet said, to preserve fragile public confidence in the economy. Throughout his comments, Trichet too sought to outsource any blame for the crisis while adopting responsibility for addressing the symptoms of the problem and framing the European response as a policy success. 


\section{January 2009: paradigm change}

In January 2009, Trichet went a lot further when he addressed a round table at the International Colloquium. In a reflective speech, he focused on what he portrayed as the underlying causes and key solutions to the crisis. He pointed to the responsibility of international financiers:

The current crisis stands out because it is affecting the heart of the global financial system. Its root cause was a widespread undervaluation of risk in the global financial system, especially in the most advanced economies. This included an underestimation of the quantity of risk financial institutions took upon themselves and an underpricing of the unit of risk. Risk was underpriced because, among other things, financial market participants largely extrapolated ongoing trends and the very low levels of volatility in financial markets and in the real economies going forward.

The European Union had, in contrast (according to Trichet), 'reacted promptly' and in a coordinated manner to prevent 'contagion'. The ECB President further hammered financial firms and argued that short-term thinking and excessive risk taking were directly to blame for the crisis:

Among financial market participants (traders, managers, risk committees and boards of directors alike) for a long time there has been an excessive focus on short-term profits to the detriment of longer-term business performance. This has resulted in excessive risk-taking and, particularly, an underestimation of low probability risks stemming from excessive leverage and concentration.

He also outlined his views about the appropriate response and called for increased transparency and regulation in the banking sector. Like his colleagues at the commission, Trichet praised the European institutions for their quick action:

The swiftness and the magnitude of the decisions taken by central banks as regards the supply of liquidity and the decisive actions taken by governments and parliaments as regards recapitalisation in the financial sector and the provision of guarantees have proved effective in avoiding a meltdown of global finance.

He concluded by arguing that the necessary response to the present situation was to engage in a 'paradigm change' in the global economy, away from short-term thinking to an approach based on 'medium and long-term sustainability' (but was otherwise low on the specifics of such an alternative 'paradigm'). Again, the dominant framing sought was one of exogenous responsibility but a 'domestic' opportunity and responsibility to enact a new regulatory system and a success story so far for the European response. 


\section{April 2009: Chatham House speech}

As the pressures of a collapsing European economy mounted, Trichet became even less circumspect when he addressed the Chatham House Global Financial Forum on 27 April 2009. He now blamed the crisis squarely on the finance and banking sector's 'unfettered speculation and financial gambling' instead of the management of 'genuine' economic risk. Though 'financial liberalisation and financial innovation had made a significant contribution to the economy', there had been a simultaneous weakening of the screening procedures for credit, which had resulted in a decline in underwriting standards and lending responsibility.

Trichet told his audience that the ECB's main response to the crisis was to lower interest rates, followed by a guarantee for European banks designed to back up liquidity. There was an imperative to manage the crisis and improve productivity by increasing and maintaining public confidence in the euro and the European economy. Trichet said that ensuring the continued viability of Europe's banks was his primary concern and a foundation for potential recovery. In all, this third speech was less of an exercise in self-praise than his previous 'paradigm change' speech and more of an apportionment of (exogenous) blame and plans for mitigation.

\section{Media response to Trichet's framing}

The New York Times lauded the 'historic pace' of the reduction in interest rates across the globe, but especially in Europe, in an article on 4 December 2008 (Dougherty 2008). The article also highlighted divisions between Trichet, the European Commission and European governments over the pace of change. It suggested that despite the unprecedented reduction in rates, 'The European Central Bank's reluctance to outline a more forceful strategy for the future exposes it to the charge that it is underestimating the severity of the downturn, and that it is passing on opportunities to get ahead of it, analysts said' (Dougherty 2008).

At the press conference for the reduction in ECB interest rates itself, Trichet faced questions about whether such a significant reduction might have a detrimental impact on market confidence (which he claimed was his primary concern), and whether his focus as the President of the ECB on rates alone was too narrow to appropriately address the crisis.

The primary framing contest over the $\mathrm{ECB}^{\prime}$ s interest rate cut (the only one of Trichet's three key statements analysed here to attract significant media attention in the sources used) was in regard to the reduction in rates and whether this represented an appropriate response. Furthermore, questions seemed to exist about whether the rate cut was substantial enough or even too substantial. More 
broadly, Trichet appeared to work hard to characterise the crisis as the result of excessive risk taking in the financial sector.

\section{Member state leaders: the road to collaboration}

As discussed earlier in this chapter, it is impossible to divorce decision making at the EU institutional level from the thoughts and actions of leaders of the member states, particularly the larger states such as France, Germany and the United Kingdom. The leaders of those three key EU member states are used here to shine additional light on the public and political impacts of Barroso's, Almunia's and Trichet's efforts to frame the severity, causes and implications of the crisis in particular ways.

French President Sarkozy, German Chancellor Merkel and British Prime Minister Brown demonstrated a remarkable consistency of views in the public arena once the initial 'cascade' of hasty national decisions to guarantee bank deposits had run its course. From late 2008 onwards, more coordination took place at the EU level, especially in the lead-up to the G20 summit. Initially, however, there was significant disagreement about the size and necessity of stimulus packages and the extent of new banking regulation, with Germany holding out for a more fiscally conservative line. As the New Year rolled over, however, the extent of agreement on the necessity for European cooperation on new regulation and stimulus and the need to rethink the commitment to unrestrained markets became remarkable. The statements of the various national leaders mirror that evolution.

As early as September 2008, The Washington Post had reported on a speech that Sarkozy had given in Toulon (see also Windle, this volume), in which the French President had

joined a broad spectrum of European leaders and commentators who have interpreted the financial crisis as a death knell for the current financial markets and banking systems. Their comments sometimes have betrayed an 'I told you so' sentiment, after years during which US officials suggested that many of Europe's economic problems stemmed from an excess of regulation and government intervention. (Cody 2008)

As the crisis gathered pace in September, Merkel's rhetoric was strongly geared towards harsh criticism of policymaking in Washington. Her government rejected the need to provide a stimulus package or bailout for the German financial system (Der Spiegel 2008). And, in early December, while Brown, Sarkozy and Barroso all called for more cooperation between EU leaders to respond to the economic crisis, Merkel continued to resist the need for a stimulus package and refused to commit to funding the commission's stimulus plan. 'Merkel has said for the past 10 days that she would not join in a race to spend billions of taxpayers' euros as one way to stimulate the economy and instead would take her time and 
assess what short- and long-term measures to take' (Werdigier and Dempsey 2008).

By late January 2009, however, Germany had implemented a stimulus package of its own and was supporting the European stimulus plan. It was now in lockstep with France and Britain in calling for tighter regulation of financial markets and increased European cooperation (Connolly 2009; Fincher 2009). It was a major U-turn, and it was clear that Merkel's government had given in to economic reality and EU pressure. By the time the G20 summit rolled around towards the end of March 2009, Germany, France and Britain had all adopted the same policy response to the crisis, as separate states and as part of the EU institutions. It was clear that all three leaders had adopted a joint enthusiasm for government intervention in the economy, including intensive European cooperation. Their rhetoric began to reflect this. It appeared more likely that they had been convinced by each other, rather than by Barroso, but nonetheless it was clear that the key European leaders had come to accept the crisis framing and policy stances that had been adopted consistently by the EU institutional leaders early on.

\section{Conclusions: the power of rhetoric or the power of interdependence?}

The three key EU players attempted to mobilise support for major, closely coordinated policy change in response to the crisis. Barroso, Almunia and Trichet all identified the crisis as a profound event with exogenous causes. There was a consistent pattern of attempting to apportion blame for the crisis to excessive risk taking and the unrestrained capitalistic behaviour of private banks and financial institutions, studiously avoiding mention of any regulatory deficiencies either at the EU or the national level (for example, the allegedly 'soft' UK system of banking regulation, which had tolerated and even encouraged precisely that kind of behaviour). The assessment of the severity of the crisis was also consistent across the three EU protagonists: they identified and expressed the global financial crisis as a significant risk to the existing economic structure and to growth, productivity and employment. All three made credible statements about what the crisis meant for Europe, across the months sampled here.

In general, though some media coverage was critical of the success or timeliness of the European Union's decision making and policy program, it appears that the message of key opportunities for substantial structural change and increased European cooperation and coordination broke through, and gained traction among the media and the leaders of three key member states discussed above. The best proof of this came from the unified approach taken by the European Union at the G20 summit after successful cooperation before the event. The available coverage of the European response to the crisis revealed few complaints that the commission and the ECB had failed to act appropriately or that the 
European Union's stated goals of increased regulation and European cooperation were not the universally favoured outcomes. Each of the European leaders had acted decisively, on a broad scale, and in tune with their EU colleagues and the commission.

The remarkable turnaround in German political opinion on how best to address the crisis and the consistent pattern of exogenous blame shifting and type- 3 opportunity-seeking rhetoric from the EU institutional leaders and the three key member state leaders could be construed as evidence of how successful these actors were in framing the crisis and creating their desired meaning. It was someone else's fault (the United States, the financial sector) and the commitment to free markets had to be reconsidered where a clear need existed for the European Union and EU member states to directly intervene in their economies to address the crisis.

The most substantial gain achieved by the three EU actors during the period analysed by this chapter was an increased level of European cooperation on the functions of the banking and finance system. Each time a leader made a speech or a statement, the primary stated cause of the crisis was the various failures of the international banking and finance system, and each time a solution was proposed it was either a temporary stabilisation measure or a substantial and pan-European structural reform designed to reduce the potential for a repeat crisis. As the timeline moved forward, it became clear that a consensus had emerged that strong collective regulatory action was an appropriate response to the crisis. The rhetoric strongly suggested that a substantial paradigm shift had occurred in the political and policy realm: for the Europeans, there was a new mandate for government intervention in the economy and a new legitimacy for European Union-wide economic action. What is less clear, however, is whether these shifts occurred because of the inherent persuasiveness of the EU actors' discourse. Perhaps, in line with Lindberg and Scheingold's (1970) classic statement on the pivotal role of crises in forging European integration, member state leaders came to the party because the sheer pressure of economic realities left them with little room to manoeuvre.

\section{References}

Almunia, J. 2008, A recipe for recovery: the European response to the financial crisis, Speech to the second Brussels International Economic Forum, 11 November, viewed 30 May 2009, $<$ http://europa.eu/rapid/pressReleasesAction.do?reference=SPEECH/ 08/601 \&format $=$ HTML\&aged $=0$ \&language $=$ EN\&guiLanguage $=$ en $>$

Almunia, J. 2009, Spring forecast 2009, Speech, 4 May, viewed 30 May 2009, $<$ http://ec.europa.eu/commission_barroso/almunia/iframes/ conferences/2009/files/09_05_04_speakings.pdf > 
Atkins, R. and Barber, T. 2009, 'Europe has sown seeds of slow recovery', The Financial Times, 25 February, viewed 30 May 2009, <http://www.ft.com/cms/s/de3b2af8-0371-11de-b405-000077b0765>

Barber, T. 2008, 'EU urged to accelerate reforms', The Financial Times, 11 November, viewed 30 May 2009, <http://www.ft.com/cms/s/0/ 9771bdba-afe0-11dd-a795-0000779fd18c.html?nclick_check=1 >

Barroso, J. 2008a, From financial crisis to recovery: a European framework for action, Remarks to the extraordinary European Commission meeting, Brussels, 29 October, viewed 29 May 2009, $<$ http://europa.eu/rapid/pressReleasesAction.do?reference $=\mathrm{SPEECH} /$ 08/566\&format $=$ HTML\&aged $=0$ \&language $=$ EN\&guiLanguage $=e n>$

Barroso, J. 2008b, A European economic recovery plan, Press conference, Brussels, 26 November, viewed 29 May 2009, $<$ http://europa.eu/rapid/pressReleasesAction.do?reference $=\mathrm{SPEECH} /$ 08/654\&format $=$ HTML\&aged $=0$ \&language $=$ EN\&guiLanguage $=e n>$

Barroso, J. 2009a, Opening remarks, European Commission meeting, Brussels, 25 February, viewed 29 May 2009, $<$ http://europa.eu/rapid/pressReleasesAction.do?reference=SPEECH/ 09/76\&format $=$ HTML\&aged $=0$ \&language $=$ EN\&guiLanguage $=e n>$

Barroso, J. 2009b, The G20-a unique opportunity, Press conference, Brussels, 31 March, viewed 29 May 2009, $<$ http://europa.eu/rapid/pressReleasesAction.do?reference $=$ SPEECH/ 09/160\&format $=$ HTML\&aged $=0$ \&language $=$ EN\&guiLanguage $=$ en $>$

Boin, A., 't Hart, P. and McConnell, A. 2009, 'Crisis exploitation: political and policy impacts of framing contests', Journal of European Public Policy, vol. 16, no. 1, pp. 81-106.

Castle, S. and Jolly, D. 2008, 'Giant stimulus plan proposed for Europe', The New York Times, 26 November, viewed 30 May 2009, <http://www.nytimes.com/2008/11/27/business/worldbusiness/ 27euro.html?_r=1\&scp=12\&sq=EU $\% 20$ and $\% 20 \% 22$ financial $\% 20$ crisis $\% 22 \% 20$ and $\% 20 \% 22$ barroso $\% 22 \&$ st $=$ cse $>$

Cody, E. 2008, 'Sarkozy advocates systemic change after crisis', The Washington Post, 26 September, viewed 25 May 2009, $<$ http://www.washingtonpost.com/wp-dyn/content/article/ 2008/09/25/AR2008092504285.html >

Connolly, K. 2009, 'Germany approves €50bn stimulus package', The Guardian, 27 January, viewed 25 May 2009, <http://www.guardian.co.uk/world/2009/jan/27/germany-europe> 
Der Spiegel 2008, 'Financial crisis puts Merkel in hot seat', Der Spiegel, 12 August, viewed 25 May 2009,

<http://www.spiegel.de/international/germany/0,1518,595044,00.html>

Dougherty, C. 2008, '3 European central banks cut rates', The New York Times, 4 December, viewed 1 May 2009,

$<$ http://www.nytimes.com/2008/12/05/business/worldbusiness/

05euro.html?_r=2\&scp=11\&sq=EU \%20and $\% 20 \% 22$ financial $\% 20$

crisis $\% 22 \% 20$ and $\% 20 \% 22$ trichet $\% 22 \& s t=$ cse $>$

Fincher, C. 2009, 'Brown, Merkel urge tighter global banking supervision', Reuters, 28 February, viewed 25 May 2009, $<$ http://www.reuters.com/article/idUSLS40256720090228>

Gow, D. 2009, 'EU leaders back clampdown on hedge funds and private equity firms', The Guardian, 24 February, viewed 10 July 2009, <http://www.guardian.co.uk/business/2009/feb/23/ eu-clampdown-on-private-equity $>$

Lindberg, L. N. and Scheingold, S. A. 1970, Europe's Would-Be Polity: Patterns of change in the European Community, Prentice-Hall, Englewood Cliffs.

McCormick, J. 2005, Understanding the European Union: A concise introduction, Palgrave Macmillan, New York.

Tallberg, J. 2006, Leadership and Negotiation in the European Union, Cambridge University Press, Cambridge.

Traynor, I. 2008, 'Europe announces $€ 200$ bn rescue plan', The Guardian, 26 November, viewed 29 June 2009, $<$ http://www.guardian.co.uk/business/2008/nov/26/ europe-economic-recovery-plan>

Trichet, J.-C. 2008, Introductory statement with Q\&A, Announcement on interest rates, Brussels, 4 December, viewed 1 May 2009, <http://www.ecb.int/press/pressconf/2008/html/is081204.en.html>

Trichet, J.-C. 2009a, A paradigm change for the global financial system, Speech to the International Colloquium, Paris, 9 January, viewed 1 May 2009, <http://www.ecb.int/press/key/date/2009/html/sp090109.en.html>

Trichet, J.-C. 2009b, The financial crisis and our response so far, Speech to the Chatham House Global Financial Forum, New York, 27 April, viewed 1 May 2009, <http://www.ecb.int/press/key/date/2009/html/sp090427.en.html>

Verbeek, B. (forthcoming), 'Leadership of international organizations', in J. Kane, H. Patapan and P. 't Hart (eds), Dispersed Democratic Leadership: Origins, dynamics and implications, Oxford University Press, Oxford. 
Framing the global economic downturn

Werdigier, J. and Dempsey, J. 2008, 'European leaders call for closer cooperation on economic crisis', The New York Times, 8 December, viewed 10 July 2009, <http://www.nytimes.com/2008/12/08/business/worldbusiness/ 08iht-summit.4.18499082.html>

\section{Endnotes}

1 The effort to construct a media analysis in this case was hampered partly by practical difficulties. The author is monolingual and, while a combination of leading national papers and magazines in the main member states (such as Le Monde, Le Soir, Frankfurter Allgemeine and Der Spiegel) would constitute a credible proxy of 'European public opinion', their English-language web sites were either limited in their coverage or had inadequate search engines. 